\title{
Co-production of amino acid-rich xylooligosaccharide and single-cell protein from paper mulberry by autohydrolysis and fermentation technologies
}

\author{
Yang $\mathrm{Gu}^{1 \dagger}$, Yingying $\mathrm{Hu}^{1 \dagger}$, Caoxing Huang ${ }^{1}$, Chenhuan Lai ${ }^{1}$, Zhe Ling ${ }^{1,2}$ and Qiang Yong ${ }^{1 *}$
}

\begin{abstract}
Background: Autohydrolysis is an extensively investigated pretreatment method due to its environmental friendliness. During autohydrolysis, most xylan from hemicellulose can be converted into xylooligosaccharides (XOS), and cellulose in the autohydrolyzed residues can be transformed into glucose after enzymatic hydrolysis. Both of these are value-added biochemicals in the biorefining process. In this work, paper mulberry (PM), which contains abundant protein, was utilized as a raw material to coproduce XOS and single-cell protein (SCP) through autohydrolysis and fermentation technologies.

Results: The results showed that $8.3 \mathrm{~g}$ of XOS and $1.8 \mathrm{~g}$ of amino acids could be recovered in the autohydrolysate (based on $100 \mathrm{~g}$ raw material) after autohydrolysis $\left(170^{\circ} \mathrm{C}, 1 \mathrm{~h}\right.$ ). Moreover, $5.7 \mathrm{~g}$ of low-DP XOS along with $1.8 \mathrm{~g}$ of

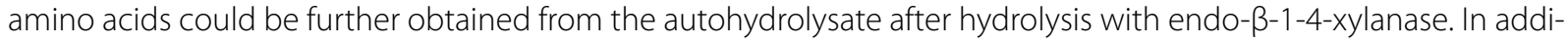
tion, $20.1 \mathrm{~g}$ of fermentable monosaccharides was recovered after hydrolyzing the autohydrolyzed PM with cellulase, which can be used to produce $4.8 \mathrm{~g}$ of SCP after fermentation with Candida utilis.
\end{abstract}

Conclusion: As a valuable application of PM, a novel process is proposed to coproduce amino acid-rich XOS and SCP through autohydrolysis. The carbohydrate of PM is effectively converted to high value-added products.

Keywords: Paper mulberry, Autohydrolysis, Xylooligosaccharide, Amino acids, Single-cell protein

\section{Background}

Paper mulberry (Broussonetia papyrifera, PM), a hardwood from the Moraceae family, is widely distributed in East and South Asia and exhibits fast growth, ease of breeding, strong tillering ability, and pruning resistance $[1,2]$. In East Asia, the plant cortex of PM is widely used as a raw material for paper manufacture [3], and the fruit

\footnotetext{
*Correspondence: swhx@njfu.com.cn

${ }^{\dagger}$ Yang Gu and Yingying Hu contributed equally to this work, regarding as the first author.

1 Jiangsu Co-Innovation Center of Efficient Processing and Utilization of Forest Resources, College of Chemical Engineering, Nanjing Forestry University, Nanjing 210037, China

Full list of author information is available at the end of the article
}

from PM is used as a traditional medicinal for its pharmacological effects such as antioxidant [4], anti-inflammatory [4], and immunomodulation activities [2], and as a treatment for Alzheimer's disease [5]. Additionally, the leaves of PM are ensilaged for livestock farming due to their rich dietary fiber. However, the branches and twigs remain unutilized components of PM. Interestingly, these branches and twigs contain not only cellulose, hemicellulose and lignin as regular lignocellulosic biomasses but also abundant protein. Hence, the branches and twigs of PM are attractive substrates for the biorefinery process to obtain hemicellulose and cellulose as high-value products as well as providing other biomass [6]. However, it is difficult to effectively separate hemicellulose from cellulose original author(s) and the source, provide a link to the Creative Commons licence, and indicate if changes were made. The images or other third party material in this article are included in the article's Creative Commons licence, unless indicated otherwise in a credit line to the material. If material is not included in the article's Creative Commons licence and your intended use is not permitted by statutory regulation or exceeds the permitted use, you will need to obtain permission directly from the copyright holder. To view a copy of this licence, visit http://creativecommons.org/licenses/by/4.0/. The Creative Commons Public Domain Dedication waiver (http://creativeco mmons.org/publicdomain/zero/1.0/) applies to the data made available in this article, unless otherwise stated in a credit line to the data. 
due to their compact structure. Therefore, an appropriate pretreatment method is necessary for the coproduction of amino acid-rich XOS and fermentable monosaccharides from PM. Through pretreatment, most of the xylan in the hemicellulose can be converted into value-added chemicals such as xylooligosaccharides (XOS) and xylose, and the cellulose can be enzymatically hydrolyzed into glucose for further fermentation [7]. Meanwhile, the protein can be degraded into amino acids. Therefore, the pretreatment method is the key to the efficient utilization of PM.

Among all pretreatment technologies, autohydrolysis is considered an economical, ecofriendly, and concise pretreatment method, because it is a reagent-free treatment that relies only upon temperature and pressure to both deacetylate xylan and increase the efficiency of enzymatic hydrolysis [8]. Moreover, XOS, as one of the value-added biochemicals depolymerized from xylan, is the main product of lignocellulose autohydrolysis [9]. Furthermore, in terms of the autohydrolysis of protein-rich lignocellulose, solubilized xylan can be obtained mainly in the form of XOS, and the protein can be degraded into amino acids that can be further purified for valuable prebiotic applications [10]. Hence, autohydrolysis was used in this work to coproduce amino acid-rich XOS and fermentable monosaccharides from PM.

XOS, a type of functional oligosaccharide generated from hemicelluloses during autohydrolysis, are beneficial feed additives in human and animal diets [11]. Chemically, XOS are oligosaccharides made of 2-10 xylose molecules connected by $\beta-(1,4)$ linkages [9]. XOS with low degrees of polymerization $(\mathrm{DP} \leq 6)$, especially xylobiose and xylotriose, are particularly beneficial, because they are fermented in the hindgut and provide prebiotic effects to the consumer via selective stimulation of beneficial bacteria such as Bifidobacteria or Lactobacilli. Furthermore, research has shown that XOS can help reduce populations of pathogenic bacteria such as Escherichia coli [12, 13]. Based on these benefits, the demand for XOS has increased since the turn of the century. On the other hand, amino acids can be obtained as byproducts after autohydrolysis. Like XOS, amino acids are high-value biochemicals that can be added to the diets of humans and animals, especially essential amino acids. Essential amino acids cannot be synthesized in the human or animal body and must be ingested from food [14]. Hence, the XOS and the amino acids recovered in the autohydrolysate can be purified for further applications. Moreover, the autohydrolyzed PM can be enzymatically hydrolyzed by cellulase to produce fermentable monosaccharides.

Additionally, the fermentable monosaccharides obtained from enzymatic hydrolysis residues can be utilized for microbial fermentation. One of the topical fermentation products is single-cell protein (SCP). As a value-added biochemical, SCP is widely used in the agricultural field. SCP refers to the protein derived from cells of microorganisms grown on various carbon sources during fermentation [15]. Due to its high protein content, SCP is also called a bioprotein or microbial protein and has the potential to serve as an alternative to plant protein sources [16]. Compared with plant protein sources, $\mathrm{SCP}$ production is not subject to seasonality, nor does it rely on large areas of land and abundant water supply. SCP can be produced by various kinds of microorganisms, including yeast (e.g., Candida utilis), bacteria (e.g., Cupravidus nectar), and algae (e.g., Chlorella vulgaris) $[16,17]$. Among those, yeast is the best choice because of its high protein content, rapid growth rate, lack of pathogenicity, fast digestibility, and overall palatability [18]. Candida utilis is a typical yeast strain for producing SCP, and it can utilize agricultural residues, industrial waste and other materials as substrates [19-21]. Therefore, enzymatic hydrolysates rich in fermentable monosaccharides from biorefinery processing are an ideal substrate to produce $\mathrm{SCP}$.

In this work, a process was investigated for the coproduction of amino acid-rich XOS and SCP through autohydrolysis by utilizing the branches and twigs of PM. After autohydrolysis, hemicellulose was depolymerized into XOS, while the protein was hydrolyzed into amino acids. Afterward, the autohydrolysate and autohydrolyzed PM were hydrolyzed by endo- $\beta-1-4$-xylanase and cellulase to obtain low-DP XOS (degree of polymerization $\leq 6)$ and fermentable monosaccharides. Candida utilis was used to convert the fermentable monosaccharides into SCP. The obtained low-DP XOS, amino acids and SCP can be utilized for further applications.

\section{Results and discussion}

\section{Compositional analysis of autohydrolyzed PM}

In this work, the autohydrolysis pretreatment was carried out at $150{ }^{\circ} \mathrm{C}-190{ }^{\circ} \mathrm{C}$ for $1 \mathrm{~h}$ to evaluate how PM responded to the increase in autohydrolysis severity. The chemical compositions of autohydrolyzed PM, the recovery yield of glucan, and the removal yields of xylan, lignin and crude protein are shown in Table 1.

According to Table 1, the major components of PM are $39.4 \%$ glucan, $22.1 \%$ xylan, $24.9 \%$ lignin (acid-insoluble + acid-soluble), $6.6 \%$ crude protein and $4.3 \%$ extractive. It was found that increasing the autohydrolysis pretreatment contributed to a lower solid recovery yield. Specifically, the solid recovery yield decreased from 91.7 to $63.7 \%$ as the reaction temperature increased from 150 to $190{ }^{\circ} \mathrm{C}$. Moreover, the glucan recovery yield decreased from 98.9 to $86.2 \%$, while the xylan removal yield 
Table 1 Effect of reaction temperature on autohydrolyzed PM

\begin{tabular}{|c|c|c|c|c|c|c|c|c|c|}
\hline \multirow[t]{2}{*}{ Biomass } & \multirow[t]{2}{*}{ Glucan (\%) } & \multirow[t]{2}{*}{ Xylan (\%) } & \multirow[t]{2}{*}{ Lignin (\%) } & \multirow[t]{2}{*}{ Crude Protein (\%) } & \multicolumn{2}{|c|}{ Recovery Yield (\%) } & \multicolumn{2}{|c|}{ Removal Yield (\%) } & \multirow{2}{*}{$\begin{array}{l}\text { Degradation } \\
\text { Yield (\%) } \\
\text { Protein }\end{array}$} \\
\hline & & & & & Solid & Glucan & Xylan & Lignin & \\
\hline Raw material & $39.4 \pm 0.5$ & $22.1 \pm 0.3$ & $24.9 \pm 0.0$ & $6.58 \pm 0.0$ & & & & & \\
\hline $150^{\circ} \mathrm{C}$ & $42.5 \pm 0.5$ & $22.3 \pm 0.3$ & $23.3 \pm 0.7$ & $2.4 \pm 0.0$ & 91.7 & 98.9 & 7.5 & 14.3 & 67.1 \\
\hline $160^{\circ} \mathrm{C}$ & $45.1 \pm 0.3$ & $18.4 \pm 0.3$ & $26.5 \pm 0.5$ & $2.2 \pm 0.1$ & 81.4 & 93.1 & 32.0 & 13.4 & 73.0 \\
\hline $170^{\circ} \mathrm{C}$ & $49.6 \pm 0.2$ & $13.9 \pm 0.2$ & $28.7 \pm 0.1$ & $1.9 \pm 0.0$ & 72.4 & 91.1 & 54.4 & 16.7 & 79.5 \\
\hline $180^{\circ} \mathrm{C}$ & $53.0 \pm 0.6$ & $9.1 \pm 0.2$ & $33.9 \pm 0.1$ & $1.5 \pm 0.1$ & 67.4 & 90.6 & 72.2 & 8.2 & 84.2 \\
\hline $190^{\circ} \mathrm{C}$ & $53.3 \pm 0.3$ & $5.9 \pm 0.1$ & $38.7 \pm 0.1$ & $1.3 \pm 0.0$ & 63.7 & 86.2 & 83.1 & 1.1 & 87.4 \\
\hline
\end{tabular}

increased from 7.5 to $83.1 \%$. The glucan yield and xylan yield are consistent with those of other hardwood, such as tulip trees [22]. The reason for the results was that the autohydrolysis pretreatment leads to hydrolysis of most hemicelluloses along with a small amount of cellulose [23]. For lignin, the degree of delignification increased from 14.3 to $16.7 \%$ when the temperature was increased from 150 to $170{ }^{\circ} \mathrm{C}$. However, when the temperature was increased from 170 to $190{ }^{\circ} \mathrm{C}$, the removal yield decreased from 16.7 to $1.1 \%$. This result can be attributed to the newly formed pseudolignin, which is derived from the byproducts from cellulose and hemicellulose $[22,24]$. Only $16.7 \%$ of the original lignin was removed at $170{ }^{\circ} \mathrm{C}$, suggesting that the autohydrolysis pretreatment results in the dissolution of a small portion of lignin. Sun et al. reported that $26 \%$ of the original lignin in eucalyptus was removed by autohydrolysis at $180{ }^{\circ} \mathrm{C}$ for $15 \mathrm{~min}$, and Batalha et al. reported that $50 \%$ of the original lignin in sugarcane bagasse was removed by autohydrolysis at $180{ }^{\circ} \mathrm{C}$ for $40 \mathrm{~min}[25,26]$. The types of lignocellulosic materials respond differently to delignification under autohydrolysis conditions.

In addition, the crude protein content in PM was 6.6\%. Compared with other lignocellulosic biomasses, such as poplar $(0.03 \%)$ and larch $(0.61 \%), \mathrm{PM}$ is abundant in protein, which makes it a promising resource for amino acid production. The protein in PM can be degraded into amino acids during autohydrolysis pretreatment. As shown in Table 1, the degradation yield of protein increased from 67.1 to $87.4 \%$ when the temperature was increased from 150 to $190{ }^{\circ} \mathrm{C}$. The increased yield can be attributed to the enhanced breakage of peptide bonds in protein at high temperature during autohydrolysis.

\section{Compositional analysis of autohydrolysate}

Many lignocellulosic biomasses, such as corncob and poplar, can be used to produce XOS through autohydrolysis. In contrast to conventional lignocellulosic biomasses, $\mathrm{PM}$ is rich in protein, which can be degraded into amino acids during the autohydrolysis process. Additionally, most hemicelluloses were hydrolyzed, with an XOS fraction arising from this degradation [9]. To examine the effects of autohydrolysis pretreatment on XOS and amino acid production, the chemical composition of autohydrolysate was analyzed and is shown in Tables 2 and 3.

As shown in Table 2, the concentration of total XOS in the autohydrolysate displayed an increasing trend, and subsequently decreased with increasing reaction temperature. The maximum total XOS concentration was $11.0 \mathrm{~g} / \mathrm{L}$ and was achieved at $170{ }^{\circ} \mathrm{C}$. However, when the temperature was over $170{ }^{\circ} \mathrm{C}$, the total XOS yield declined, because the original xylan was depolymerized into xylose or excessively degraded to dehydration products. The highest total XOS yield of $37.4 \%$ $\left(170{ }^{\circ} \mathrm{C}, 1 \mathrm{~h}\right)$ was in good agreement with other lignocellulosic biomasses, such as eucalyptus and mango seed shell, which were $42 \%$ and $39 \%$, respectively [27, 28]. Generally, the most effective XOS as a prebiotic for

Table 2 Effect of reaction temperature on autohydrolysate

\begin{tabular}{|c|c|c|c|c|c|c|c|c|c|c|c|c|c|}
\hline \multirow[t]{2}{*}{ Biomass } & \multicolumn{5}{|c|}{$X 2-X 6 /(g / L)$} & \multirow[t]{2}{*}{$X 2-X 6$ (g/L) } & \multirow{2}{*}{$\begin{array}{l}\text { XOS } \\
(D P>6) \\
(g / L)\end{array}$} & \multirow[t]{2}{*}{ Total XOS (g/L) } & \multirow{2}{*}{$\begin{array}{l}\text { Amino } \\
\text { acid } \\
\text { (g/L) }\end{array}$} & \multirow[t]{2}{*}{ Protein $(\mathrm{g} / \mathrm{L})$} & \multirow[t]{2}{*}{ X2-X6 Yield (\%) } & \multirow{2}{*}{$\begin{array}{l}\text { Total XOS } \\
\text { Yield (\%) }\end{array}$} & \multirow{2}{*}{$\begin{array}{l}\text { Amino acic } \\
\text { Yield (\%) }\end{array}$} \\
\hline & $x_{2}$ & $x_{3}$ & $X_{4}$ & $x_{5}$ & $x_{6}$ & & & & & & & & \\
\hline $150^{\circ} \mathrm{C}$ & 0.0 & 0.2 & 0.0 & 0.1 & 0.0 & 0.3 & 0.0 & 0.3 & 2.3 & 0.5 & 1.0 & 1.2 & 28.5 \\
\hline $160^{\circ} \mathrm{C}$ & 0.1 & 0.2 & 0.2 & 0.1 & 0.2 & 0.8 & 4.4 & 5.2 & 2.1 & 0.5 & 2.5 & 17.4 & 26.0 \\
\hline $170^{\circ} \mathrm{C}$ & 0.4 & 0.6 & 0.9 & 0.7 & 0.6 & 3.1 & 8.5 & 11.6 & 2.4 & 0.5 & 10.5 & 37.4 & 28.8 \\
\hline $180^{\circ} \mathrm{C}$ & 1.4 & 1.3 & 1.3 & 0.8 & 0.5 & 5.3 & 2.7 & 8.0 & 2.4 & 0.5 & 17.8 & 27.1 & 29.1 \\
\hline $190^{\circ} \mathrm{C}$ & 0.4 & 0.3 & 0.1 & 0.0 & 0.0 & 0.7 & 0.7 & 1.4 & 2.6 & 0.6 & 2.4 & 4.8 & 32.6 \\
\hline
\end{tabular}


Table 3 The types and amounts of amino acid in autohydrolysate

\begin{tabular}{llllll}
\hline Temperature & $\mathbf{1 5 0}{ }^{\circ} \mathbf{C}$ & $\mathbf{1 6 0}{ }^{\circ} \mathbf{C}$ & $\mathbf{1 7 0}{ }^{\circ} \mathbf{C}$ & $\mathbf{1 8 0}{ }^{\circ} \mathbf{C}$ & $\mathbf{1 9 0}{ }^{\circ} \mathbf{C}$ \\
\hline Thr (g/L) & 0.13 & 0.13 & 0.10 & 0.11 & 0.13 \\
Val (g/L) & 0.11 & 0.10 & 0.13 & 0.16 & 0.14 \\
Met (g/L) & 0.04 & 0.04 & 0.04 & 0.06 & 0.08 \\
Ile (g/L) & 0.12 & 0.10 & 0.12 & 0.12 & 0.12 \\
Leu (g/L) & 0.21 & 0.15 & 0.20 & 0.20 & 0.25 \\
Phe (g/L) & 0.13 & 0.13 & 0.11 & 0.12 & 0.14 \\
Lys (g/L) & 0.22 & 0.13 & 0.16 & 0.17 & 0.17 \\
His (g/L) & 0.07 & 0.07 & 0.06 & 0.07 & 0.08 \\
Arg (g/L) & 0.16 & 0.16 & 0.15 & 0.17 & 0.17 \\
Asp (g/L) & 0.18 & 0.14 & 0.15 & 0.18 & 0.25 \\
Ser (g/L) & 0.10 & 0.13 & 0.13 & 0.13 & 0.13 \\
Glu (g/L) & 0.40 & 0.35 & 0.44 & 0.38 & 0.40 \\
Pro (g/L) & 0.08 & 0.10 & 0.11 & 0.08 & 0.08 \\
Gly (g/L) & 0.12 & 0.14 & 0.15 & 0.14 & 0.14 \\
Ala (g/L) & 0.13 & 0.10 & 0.16 & 0.12 & 0.13 \\
Cys (g/L) & 0.01 & 0.01 & 0.02 & 0.01 & 0.03 \\
Tyr (g/L) & 0.12 & 0.12 & 0.13 & 0.13 & 0.14 \\
E (g/L) & 2.32 & 2.12 & 2.35 & 2.38 & 2.58 \\
\hline
\end{tabular}

feed additives are those with degrees of polymerization less than or equal to 6 . Hence, the abundance of these target XOS was analyzed for the hydrolysate from PM with increasing pretreatment temperature (Table 2). According to Table 2, the low-DP XOS yield was $10.5 \%$ at $170{ }^{\circ} \mathrm{C}$, which means that $26.9 \%$ XOS $(\mathrm{DP}>6)$ was formed. The XOS $(\mathrm{DP}>6)$ content shows great potential for improving low-DP XOS production by enzymatic hydrolysis.

The results in Table 2 show that the yield of amino acids based on the original amino acid content increased with increasing reaction temperature. Considering that the optimal total XOS yield was obtained at $170{ }^{\circ} \mathrm{C}$ and that the optimal amino acid yield was $32.6 \%$ at $190{ }^{\circ} \mathrm{C}$, which was only slightly higher than that at $170{ }^{\circ} \mathrm{C}(28.8 \%)$, the optimal temperature for amino acid and XOS production was $170{ }^{\circ} \mathrm{C}$. Amino acids have been used in the diets of agricultural animals since the 1950s [29]. Hence, the amino acids found in the hydrolysate could be used as a byproduct and added to the diet of agricultural animals. The specific types and amounts of amino acids are listed in Table 3. Among the 17 amino acids in the autohydrolysate, 9 are essential amino acids for animals, including threonine, valine, methionine, isoleucine, leucine, phenylalanine, lysine, histidine and arginine, which together accounted for $45.9 \%$ of the total amino acid fraction. The amino acids recovered in the autohydrolysate showed the potential to be used as feed additives after purification.

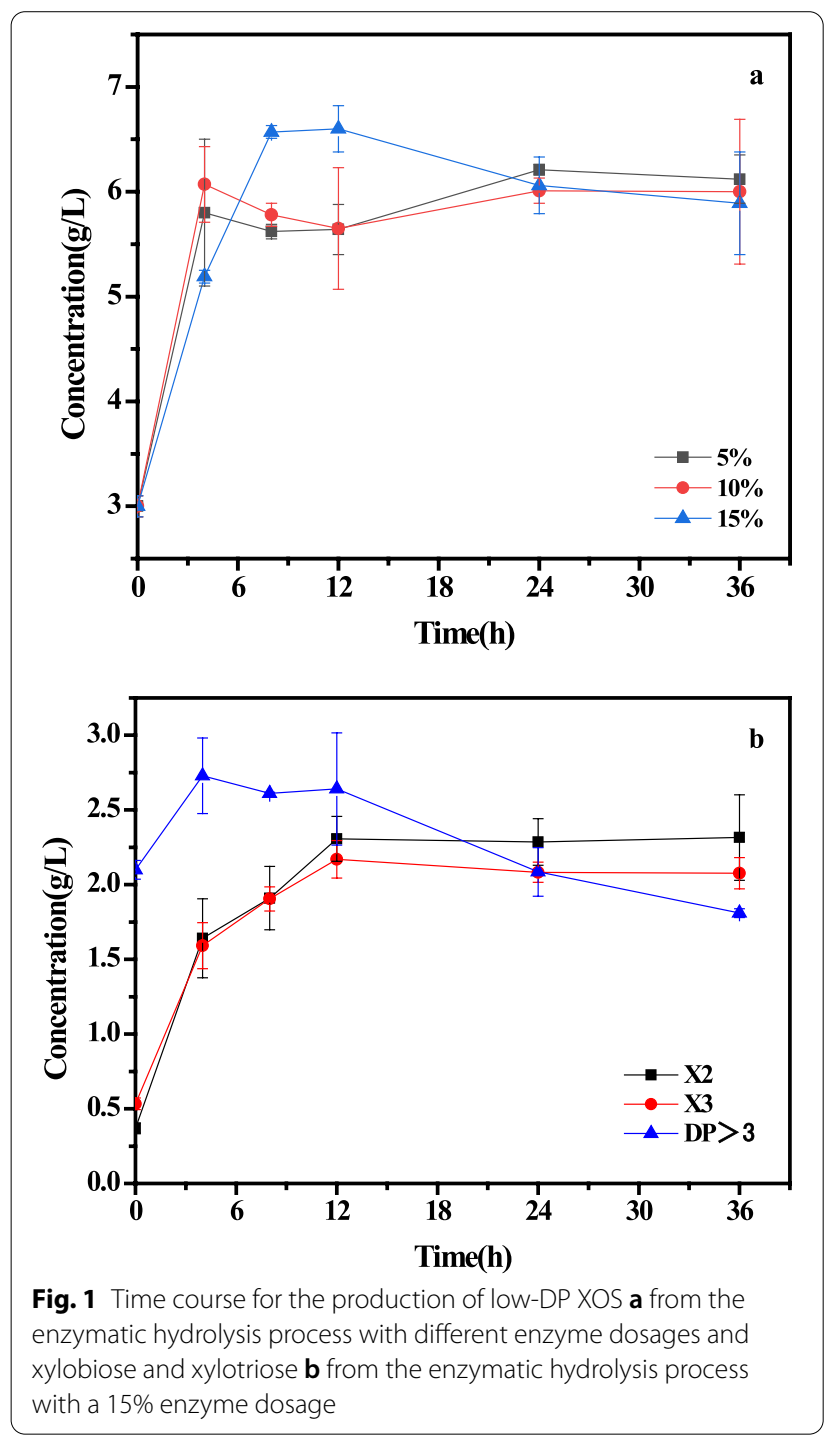

\section{Optimization of the enzymatic hydrolysis of autohydrolysate}

In vitro assays have proven that intestinal bifidobacteria prefer to metabolize xylobiose and xylotriose over highDP XOS, with xylobiose usually undergoing preferential consumption from a DP-varying mixture of XOS [10]. According to the aforementioned results, the proportion of low-DP XOS in the XOS mixture obtained from autohydrolysis pretreatment was $27.7 \%$, which was less than desired. To increase the yield of low-DP XOS, especially the yield of xylobiose and xylotriose, a strategy of mild enzymatic hydrolysis of the autohydrolysate was performed using endo- $\beta-1-4$-xylanase. Different enzyme dosages (5\%, $10 \%$ and $15 \%$ ) were added to hydrolyze the autohydrolysate $\left(170{ }^{\circ} \mathrm{C}, 1 \mathrm{~h}\right)$ samples. The concentrations of low-DP XOS obtained from enzymatic hydrolysis are shown in Fig. 1. 
It was shown that the concentration of low-DP XOS increased with increasing enzyme dosage, and the concentration of low-DP XOS increased from $3.1 \mathrm{~g} / \mathrm{L}$ to $6.6 \mathrm{~g} / \mathrm{L}$ at a substrate loading of $15 \%(\mathrm{v} / \mathrm{v})$ within $12 \mathrm{~h}$ of enzymatic hydrolysis. Moreover, the concentrations of xylobiose and xylotriose stopped increasing at this substrate loading, maintaining $2.3 \mathrm{~g} / \mathrm{L}$ and $2.2 \mathrm{~g} / \mathrm{L}$ until the end of $36 \mathrm{~h}$ of enzymatic hydrolysis, respectively. However, the concentration of XOS $(3<\mathrm{DP} \leq 6)$ continued to decline after $12 \mathrm{~h}$ of enzymatic hydrolysis until the end of the process. The observed increase in xylobiose and xylotriose production occurred concurrently with the decline in XOS $(\mathrm{DP}>3)$, illustrating that endo- $\beta-1-4$-xylanase can effectively cleave fragments of xylobiose and xylotriose from dissolved high-DP XOS. After $12 \mathrm{~h}$ of enzymatic hydrolysis, $68.7 \%$ of XOS was converted into low-DP XOS, which meant that the low-DP XOS yield was $25.8 \%$ based on the original xylan in the raw material. Overall, the concentration of low-DP XOS in the autohydrolysate was increased from $3.1 \mathrm{~g} / \mathrm{L}$ to $6.6 \mathrm{~g} / \mathrm{L}$ after enzymatic hydrolysis by endo- $\beta-1-4$-xylanase. Furthermore, the resulting amino acids in the autohydrolysate remained at the same concentration after enzymatic hydrolysis, which meant that endo- $\beta-1-4$-xylanase showed no effect on amino acids. Based on the aforementioned results, it can be seen that the low-DP XOS along with amino acids in the hydrolysate can be recovered after purification.

\section{Enzymatic hydrolysis of autohydrolyzed PM}

To explore the effects of reaction temperature on the subsequent enzymatic digestibility of the autohydrolyzed PM to produce glucose for SCP production, glucose yield (based on autohydrolyzed PM) was calculated for each enzymatic hydrolysis experiment and is shown in Fig. 2.

Figure 2 shows that autohydrolysis pretreatment with increasing reaction temperature showed positive effects on the enzymatic digestibility of glucan in the autohydrolyzed PM. Specifically, the enzymatic digestibility of glucan to glucose increased from 23.4 to $82.3 \%$ with increasing reaction temperature from 150 to $190{ }^{\circ} \mathrm{C}$. The enhanced removal of xylan and lignin might be responsible for the increased enzymatic digestibility [11]. Moreover, a small amount of xylose in comparison with glucose was also found in the enzymatic hydrolysate (glucose:xylose =4:1). Even though the highest glucose yield was obtained at $190{ }^{\circ} \mathrm{C}$, when taking into consideration the desired XOS and amino acid yields, $170{ }^{\circ} \mathrm{C}$ was considered the optimal condition for the coproduction of these final products. Hence, the carbohydrates (glucose and xylose) in the enzymatic hydrolysate from PM autohydrolyzed at $170{ }^{\circ} \mathrm{C}$ are utilized as the carbon source in the further fermentation process.

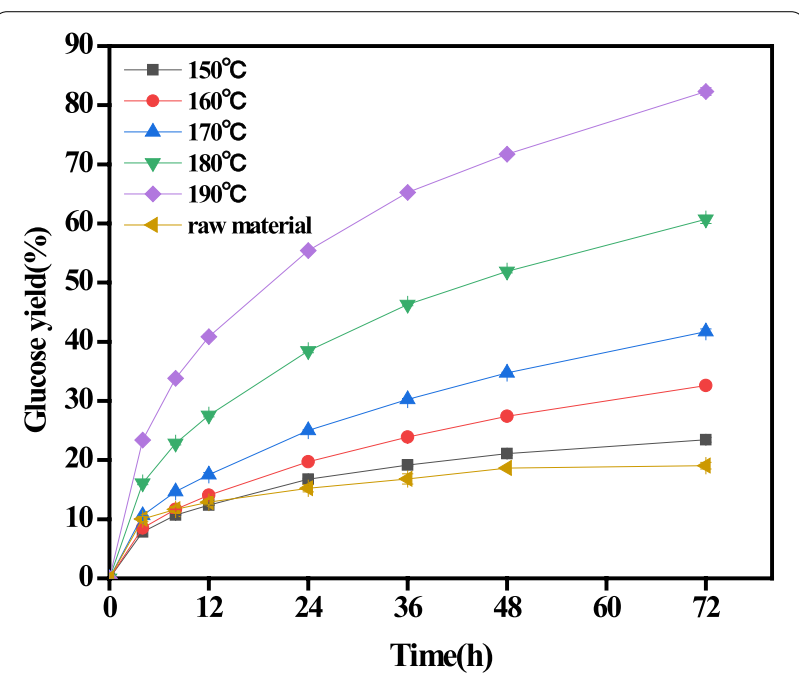

Fig. 2 Effects of different temperatures on the glucose yield of autohydrolyzed PM

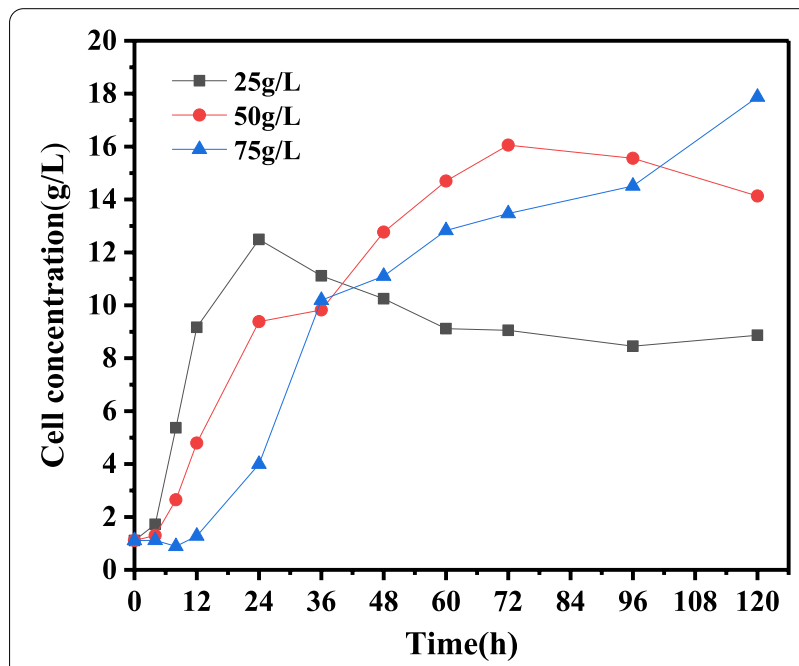

Fig. 3 Biomass concentration during $120 \mathrm{~h}$ shake-flask cultivation with $25 \mathrm{~g} / \mathrm{L}, 50 \mathrm{~g} / \mathrm{L}$ and $75 \mathrm{~g} / \mathrm{L}$ substrate concentrations of fermentable monosaccharides

\section{Optimization of SCP fermentation conditions}

To investigate the influence of substrate concentration on the production of SCP, the enzymatic hydrolysate was evaporated to different fermentable monosaccharide (glucose and xylose) concentrations of $25 \mathrm{~g} / \mathrm{L}$, $50 \mathrm{~g} / \mathrm{L}$ and $75 \mathrm{~g} / \mathrm{L}$. The enzymatic hydrolysate before and after evaporation was analyzed by HPLC and no inhibiting compounds (formic acid, acetic acid, levulinic acid, HMF and furfural) were found. The cell concentrations of SCP produced after fermentation with different substrates are shown in Fig. 3. The 
consumption of fermentable monosaccharides and the accumulation of metabolites are shown in Fig. 4.

As shown in Fig. 3, the cell concentration reached $12.5 \mathrm{~g} / \mathrm{L}$ after $24 \mathrm{~h}$ of cultivation when the substrate concentration was $25 \mathrm{~g} / \mathrm{L}$. At this time, the glucose and xylose were both completely consumed. To increase the cell concentration, the fermentable monosaccharides (glucose and xylose) in the enzymatic hydrolysate were increased to $50 \mathrm{~g} / \mathrm{L}$ and $75 \mathrm{~g} / \mathrm{L}$, which resulted in cell concentrations of $16.1 \mathrm{~g} / \mathrm{L}$ and $17.9 \mathrm{~g} / \mathrm{L}$ after $72 \mathrm{~h}$ and $120 \mathrm{~h}$ of cultivation, respectively. Under these fermentation processes, glucose and xylose were again both completely consumed. Hence, the most effective cultivation was observed when the fermentable monosaccharide (glucose and xylose) concentration was $75 \mathrm{~g} / \mathrm{L}$ after $120 \mathrm{~h}$ of cultivation, indicating that the higher substrate concentration stimulates yeast accumulation. According to the consumption of fermentable monosaccharides and the accumulation of metabolites in Fig. 4, the glucose in $75 \mathrm{~g} / \mathrm{L}$ enzymatic hydrolysate was totally consumed after $36 \mathrm{~h}$ of shake-flask cultivation, and the xylose was consumed after $120 \mathrm{~h}$ of cultivation. In addition, this phenomenon was verified when the concentration of fermentable monosaccharides in the enzymatic hydrolysate was $25 \mathrm{~g} / \mathrm{L}$ and $50 \mathrm{~g} / \mathrm{L}$, which meant that Candida utilis utilized glucose in the substrate first and then utilized xylose in the substrate after the glucose was completely consumed. Overall, the optimal substrate concentration for SCP production was enzymatic hydrolysate $\left(170{ }^{\circ} \mathrm{C}\right.$, $1 \mathrm{~h}$ ) with $75 \mathrm{~g} / \mathrm{L}$ fermentable monosaccharides (glucose and xylose).

\section{Mass balance}

To evaluate the feasibility and efficiency of the coproduction process, a mass balance (based on $100 \mathrm{~g}$ of dried PM) throughout the whole process is summarized in Fig. 5. Under the conditions of autohydrolysis at $170{ }^{\circ} \mathrm{C}$ for $1 \mathrm{~h}$, $72.4 \mathrm{~g}$ of solid was recovered from $100 \mathrm{~g}$ of dried PM, including $35.9 \mathrm{~g}$ of glucan and $10.1 \mathrm{~g}$ of xylan. In the autohydrolysate, $8.3 \mathrm{~g}$ of XOS, including $2.3 \mathrm{~g}$ of low-DP XOS, and $1.8 \mathrm{~g}$ of amino acids could be recovered. The total XOS yield and low-DP XOS yield were $37.4 \%$ and $10.5 \%$, respectively. Moreover, $28.8 \%$ of the original protein was recovered in the autohydrolysate in the form of amino acids. After $12 \mathrm{~h}$ of enzymatic hydrolysis of the autohydrolysate with endo- $\beta-1-4$-xylanase ( $15 \%$ enzyme dosage), $5.7 \mathrm{~g}$ of low-DP XOS (25.8\%) and $1.8 \mathrm{~g}$ of amino acids (28.6\%) were obtained. Then, by enzymatic hydrolysis of
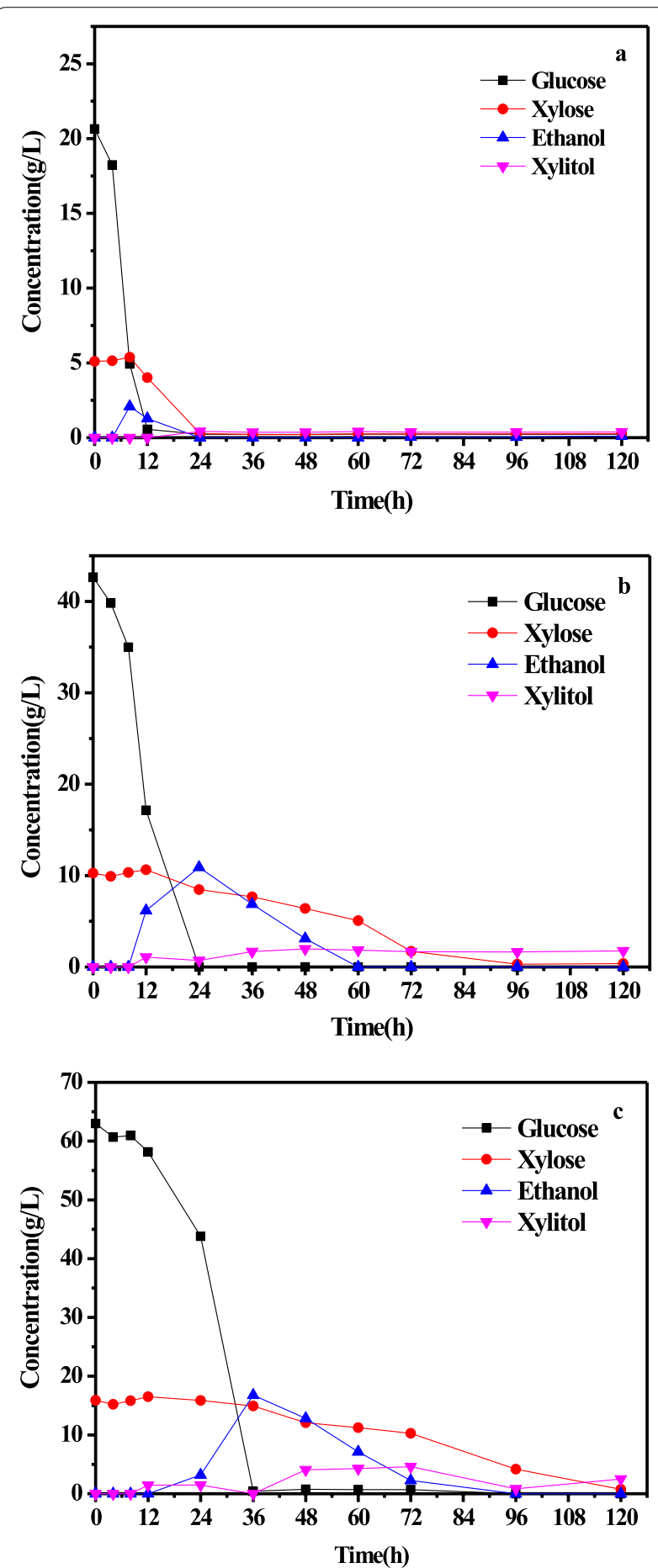

Fig. 4 Consumption of fermentable monosaccharides and the accumulation of metabolites during $120 \mathrm{~h}$ shake-flask cultivation with $25 \mathrm{~g} / \mathrm{L}(\mathbf{a}), 50 \mathrm{~g} / \mathrm{L}(\mathbf{b})$ and $75 \mathrm{~g} / \mathrm{L}$ (c) substrate concentrations of fermentable monosaccharides 


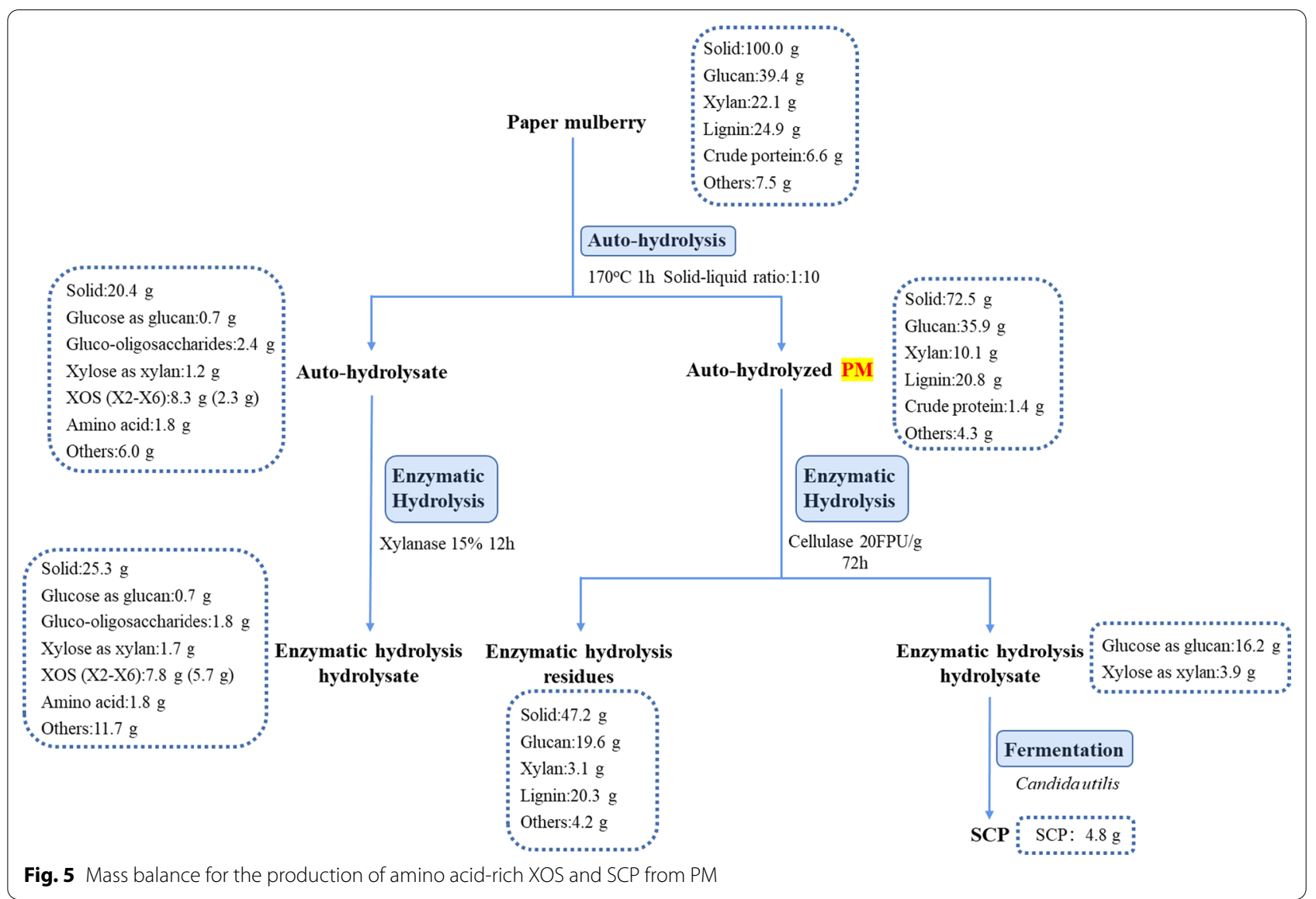

the autohydrolyzed PM $\left(170{ }^{\circ} \mathrm{C}, 1 \mathrm{~h}\right), 20.1 \mathrm{~g}$ of fermentable monosaccharides (16.2 $\mathrm{g}$ of glucose and $3.9 \mathrm{~g}$ of xylose) could be obtained for fermentation to produce $4.8 \mathrm{~g}$ of SCP. These results indicate that the branches and twigs of PM show good performance in XOS and fermentable monosaccharide production. Chen et al. reported that $14.4 \mathrm{~g}$ of XOS and $30.4 \mathrm{~g}$ of glucose could be recovered from $100 \mathrm{~g}$ of reed scraps after autohydrolysis at $170{ }^{\circ} \mathrm{C}$ for $30 \mathrm{~min}$ [30]. Neto et al. reported the optimization of XOS production through the hydrothermal pretreatment of Eucalyptus [27]. The sawdust from Eucalyptus shows the potential for the production of XOS, containing $60 \mathrm{mg}$ of XOS per gram of Eucalyptus. However, no amino acids were reported to be found in autohydrolysate from these reported lignocellulosic biomasses. Due to its high protein content, PM is an excellent raw material to coproduce the amino acid-rich XOS and SCP through autohydrolysis, enzymatic hydrolysis, and fermentation.

\section{Conclusion}

In this study, a new process was proposed to obtain amino acids, low-DP XOS and SCP from PM through autohydrolysis. After autohydrolysis $\left(170{ }^{\circ} \mathrm{C}, 1 \mathrm{~h}\right)$ and enzymatic hydrolysis (15\% enzymatic dosage), $6.6 \mathrm{~g} / \mathrm{L}$ low-DP XOS and $2.4 \mathrm{~g} / \mathrm{L}$ amino acids were produced from autohydrolysate. Autohydrolyzed PM was used to produce fermentation monosaccharides for SCP, and $17.9 \mathrm{~g} / \mathrm{L}$ SCP was obtained from enzymatic hydrolysate with $75 \mathrm{~g} / \mathrm{L}$ fermentable monosaccharides. These products, including amino acid-rich XOS and SCP showed the potential to make progress toward the industrialization of a composite feed additive as a high-value application based on low-cost autohydrolysis.

\section{Methods}

\section{Materials and reagents}

The branches and twigs of PM were harvested from the planting at the Guangzhou Academy of Forestry. After air-drying for $24 \mathrm{~h}$, the branches and twigs were ground and sieved through a 40-mesh sieve. The resultant PM sawdust was stored at room temperature until processing. The crude endo- $\beta-1-4$-xylanase used in this study was produced from Trichoderma reesei and provided by Jiangsu Kangwei Biotechnology Co., Ltd. of China. The measured enzyme activity was $30 \mathrm{U} / \mathrm{mL}$. Commercial cellulase (Cellic ${ }^{\circledR}$ CTec.2.0) was provided by Novozymes 
North America (Franklinton, NC). Bradford reagent and bovine serum protein standard solution were purchased from Sigma-Aldrich (Shanghai, China). Other chemicals, such as $\mathrm{H}_{2} \mathrm{SO}_{4}, \mathrm{MgSO}_{4}, \mathrm{CaCl}_{2}, \mathrm{KH}_{2} \mathrm{PO}_{4}$ and $\left(\mathrm{NH}_{4}\right)_{2} \mathrm{SO}_{4}$, were of analytical grade and were purchased from Nanjing Reagent Company (Nanjing, China).

\section{Autohydrolysis of PM}

For autohydrolysis pretreatment, $7 \mathrm{~g}$ of PM sawdust (based on dry weight) was pretreated in a sealed $100 \mathrm{~mL}$ reactor held in an oil bath at $150{ }^{\circ} \mathrm{C}, 160{ }^{\circ} \mathrm{C}, 170{ }^{\circ} \mathrm{C}$, $180^{\circ} \mathrm{C}$ or $190^{\circ} \mathrm{C}$ for $1 \mathrm{~h}$. The heat-up time was $30 \mathrm{~min}$. An appropriate volume of deionized water was added to the vessel to set the final solid-to-liquid ratio at 1:10. After pretreatment, the reactors were cooled by submersion in an ice water bath for $15 \mathrm{~min}$. The solid and liquid fractions were separated by vacuum filtration, and the solid fraction was washed with distilled water until the $\mathrm{pH}$ of the filtrate reached 7.0. The washed solid fraction and liquid fraction were refrigerated at $4{ }^{\circ} \mathrm{C}$ for the following experiments. The recovery yields of solids and glucan, the removal yields of xylan and lignin and the degradation yield of protein were calculated using the following formulas.

$$
\begin{aligned}
& \text { Recovery yield of Solid(\%) } \\
& \quad=\frac{\text { Mass of autohydrolyzed PM }}{\text { Mass of raw PM }} \times 100 \% \\
& \text { Recovery yield of Glucan(\%) } \\
& \quad=\frac{\text { Glucan in autohydrolyzed PM }}{\text { Glucan in raw PM }} \times 100 \% \\
& \text { Removal yield of Xylan }(\%) \\
& =1-\frac{\text { Xylan in autohydrolyzed PM }}{\text { Xylan in raw PM }} \times 100 \%
\end{aligned}
$$

$$
\text { Removal yield of Lignin }(\%)=1-\frac{\text { Lignin (acid }- \text { insoluble }+ \text { acid }- \text { soluble }) \text { in autohydrolyzed PM }}{\text { Lignin (acid }- \text { insoluble }+ \text { acid }- \text { soluble }) \text { in raw PM }} \times 100 \%
$$

milliliter samples with adjusted $\mathrm{pH}$ values were mixed with endo- $\beta-1-4$-xylanase at substrate loadings of $5 \%$, $10 \%$, and $15 \%(\mathrm{v} / \mathrm{v})$. The enzymatic hydrolysis assays were performed in a constant temperature oscillator $\left(50{ }^{\circ} \mathrm{C}\right.$, $150 \mathrm{rpm})$ for $36 \mathrm{~h}$. Aliquots $(0.5 \mathrm{~mL})$ were taken at $4 \mathrm{~h}$, $8 \mathrm{~h}, 12 \mathrm{~h}, 24 \mathrm{~h}$ and $36 \mathrm{~h}$ for HPAEC (high-performance anion exchange chromatography) analysis of the amount of low-DP XOS.

\section{Enzymatic hydrolysis of autohydrolyzed PM}

Enzymatic hydrolysis of the autohydrolyzed PM was carried out by suspending the pretreated solid biomass in sodium citrate buffer $(\mathrm{pH} 4.8)$ at $2 \%$ glucan content $(\mathrm{w} / \mathrm{v})$ with an enzyme loading of $20 \mathrm{FPU} / \mathrm{g}$ glucan. The suspensions were incubated at $50{ }^{\circ} \mathrm{C}$ and $150 \mathrm{rpm}$ for $72 \mathrm{~h}$. Aliquots $(0.6 \mathrm{~mL})$ were taken at $4 \mathrm{~h}, 8 \mathrm{~h}, 12 \mathrm{~h}, 24 \mathrm{~h}, 36 \mathrm{~h}$, $48 \mathrm{~h}, 60 \mathrm{~h}$ and $72 \mathrm{~h}$ to determine the sugar concentration by HPLC to calculate the glucose yields as follows:

$$
\begin{aligned}
& \text { Glucose yield\% } \\
& =\frac{\text { Glucose as glucan in enzymatic hydrolysate }(\mathrm{g})}{\text { initial Glucan insubstrate }(\mathrm{g})} \\
& \quad \times 100 \% .
\end{aligned}
$$

\section{Fermentation to produce SCP}

To obtain specified substrate concentrations $(25 \mathrm{~g} / \mathrm{L}$, $50 \mathrm{~g} / \mathrm{L}$ and $75 \mathrm{~g} / \mathrm{L}$ fermentable monosaccharides: glucose and xylose) from the enzymatic hydrolysate, the liquid fraction was evaporated to a particular volume by rotary evaporation. Various nutritive salts were then added to assist with fermentation, including $0.6 \mathrm{~g} / \mathrm{L} \mathrm{MgSO}_{4}$, $0.13 \mathrm{~g} / \mathrm{L} \mathrm{CaCl}{ }_{2}, 6 \mathrm{~g} / \mathrm{L} \mathrm{KH}_{2} \mathrm{PO}_{4}$, and $5 \mathrm{~g} / \mathrm{L} \mathrm{N}$ sources. The nitrogen sources were $\left(\mathrm{NH}_{4}\right)_{2} \mathrm{SO}_{4}$ and dried corn steep liquor powder at a ratio of $2: 1$. The yeast strain for fermentation was Candida utilis. This experiment was carried out in $250 \mathrm{~mL}$ flasks with a working volume of $50 \mathrm{~mL}$ at $30{ }^{\circ} \mathrm{C}$ and $170 \mathrm{rpm}$ for $120 \mathrm{~h}$. Aliquots $(1.0 \mathrm{~mL})$ were

$$
\begin{aligned}
& \text { Degradation yield of Protein }(\%) \\
& \quad=1-\frac{\text { Protein in autohydrolyzed PM }}{\text { Protein in raw PM }} \times 100 \% .
\end{aligned}
$$

\section{Enzymatic hydrolysis of autohydrolysate}

Before enzymatic hydrolysis, the autohydrolysate was first centrifuged, and filtered to remove suspended solid fractions. Next, the $\mathrm{pH}$ of the autohydrolysate was adjusted using $1 \mathrm{M}$ citrate buffer to reach $\sim 4.8$. Ten 
biomass was diluted to $4 \% \mathrm{H}_{2} \mathrm{SO}_{4}$ and autoclaved at $121{ }^{\circ} \mathrm{C}$ for $1 \mathrm{~h}$. The hydrolysate was filtered and ovendried to determine the insoluble solids, and the filtrate was collected for the determination of acid-soluble lignin (UV-Vis at $205 \mathrm{~nm}$ and 110 Abs coefficient) and monosaccharides by HPLC (high-performance liquid chromatography) equipped with an Aminex Bio-Rad HPX-87H column and a refractive index detector. Sugar analysis was performed with $0.05 \mathrm{M} \mathrm{H}_{2} \mathrm{SO}_{4}$ solution as the mobile phase flowing at a rate of $0.6 \mathrm{~mL} / \mathrm{min}$ and a column temperature of $50{ }^{\circ} \mathrm{C}$. The content of acid-insoluble lignin was determined by the weighting method. Moreover, the crude protein was determined by using the Kjeldahl method described by AOAC [32].

\section{The chemical compositional analysis of autohydrolysate}

An aliquot of autohydrolysate was hydrolyzed using 4\% sulfuric acid at $121{ }^{\circ} \mathrm{C}$ for $1 \mathrm{~h}$ to convert xylooligosaccharides into xylose. Aliquots of autohydrolysate before and after acid hydrolysis were analyzed by the same aforementioned HPLC system. The concentration of total XOS was measured by the differences in the respective xylose contents before and after acid hydrolysis. The concentration of low-DP XOS in the autohydrolysate was determined by HPAEC (Dionex ICS-3000, Thermo Fisher Scientific, Waltham, MA, USA) with a CarboPac PA 200 column (Thermo Fisher Scientific, Waltham, MA, USA) at $30{ }^{\circ} \mathrm{C}$. Eluents of $0.1 \mathrm{M} \mathrm{NaOH}$ and $0.5 \mathrm{M}$ $\mathrm{NaOAc}$ (sodium acetate) containing $0.1 \mathrm{M} \mathrm{NaOH}$ were used at a gradient elution of $0.3 \mathrm{~mL} / \mathrm{min}$. Low-DP XOS was detected using a Dionex ED 40 Electrochemical Detector in pulsed amperometry mode through the standard quadruple waveform. Additionally, an HPLC system equipped with an AccQ Tag amino acid analysis column and photodiode array detector was used to determine the types and concentrations of amino acids. The analysis was performed with ultrapure water, $60 \%$ $(\mathrm{v} / \mathrm{v})$ acetonitrile solution as the mobile phase flowing at a rate of $1 \mathrm{~mL} / \mathrm{min}$, and a column temperature of $35^{\circ} \mathrm{C}$. The concentration of protein in the autohydrolysate was quantified by Bradford assay [33]. The cell concentration was determined by spectrophotometry, where the optical density of the cell suspension was measured against a standard curve (absorbance at $600 \mathrm{~nm}$ ). The conversion of UV reading to cell biomass in $\mathrm{g} / \mathrm{L}$ follows the standard curve $\left(y=0.38 \times-0.03, R^{2}=0.9909\right)$. The concentrations of fermentable monosaccharides and metabolites in the supernatant were analyzed by the aforementioned HPLC system.

\section{Abbreviations}

XOS: Xylooligosaccharide; low-DP XOS: XOS with low degrees of polymerization (DP $\leq 6)$; SCP: Single-cell protein; NREL: National Renewable Energy Laboratory; HPLC: High-performance liquid chromatography; HPAEC: Highperformance anion exchange chromatography.

\section{Acknowledgements}

This study was funded by the National Key Research and Development Program of China (No.2019YFB1503803), and the State Key Laboratory of Pulp and Paper Engineering (Project Number 202115).

\section{Authors' contributions}

YG developed the idea for the study, performed the research and data analysis and prepared the manuscript. YYH helped to perform the experiments.

$\mathrm{CXH}, \mathrm{CHL}, \mathrm{ZL}$, and QY helped to revise the manuscript. All authors read and approved the final manuscript.

\section{Funding}

This study was funded by the National Key Research and Development Program of China (No.2019YFB1503803) and the State Key Laboratory of Pulp and Paper Engineering (Project Number 202115).

\section{Availability of data and materials}

All data generated and analyzed in this study are included in this published article.

\section{Declarations}

Ethics approval and consent to participate

Not applicable.

\section{Consent for publication}

Not applicable.

\section{Competing interests}

The authors declare that they have no competing interests.

\section{Author details}

${ }^{1}$ Jiangsu Co-Innovation Center of Efficient Processing and Utilization of Forest Resources, College of Chemical Engineering, Nanjing Forestry University, Nanjing 210037, China. ${ }^{2}$ State Key Laboratory of Pulp Paper Engineering, South China University of Technology, Guangzhou 510640, China.

Received: 4 August 2021 Accepted: 18 December 2021

Published online: 07 January 2022

\section{References}

1. Peng X, Liu H, Chen P, Tang F, Hu Y, Wang F, et al. A Chromosomescale genome assembly of paper mulberry (Broussonetia papyrifera) provides new insights into its forage and papermaking usage. Mol Plant. 2019;12:661-77.

2. Han Q, Wu Z, Huang B, Sun L, Ding C, Yuan S, et al. Extraction, antioxidant and antibacterial activities of Broussonetia papyrifera fruits polysaccharides. Int J Biol Macromol. 2016;92:116-24.

3. Tian JL, Liu TL, Xue JJ, Hong W, Zhang Y, Zhang DX, et al. Flavanoids derivatives from the root bark of Broussonetia papyrifera as a tyrosinase inhibitor. Ind Crops Prod. 2019;138:111445.

4. Malaník M, Treml J, Leláková V, Nykodýmová D, Oravec M, Marek J, et al. Anti-inflammatory and antioxidant properties of chemical constituents of Broussonetia papyrifera. Bioorg Chem. 2020;104:104298.

5. Ryu HW, Curtis-Long MJ, Jung S, Jeong IY, Kim DS, Kang KY, et al. Anticholinesterase potential of flavonols from paper mulberry (Broussonetia papyrifera) and their kinetic studies. Food Chem. 2012;132:1244-50.

6. Zhang Q, Li M, Luo B, Luo Y, Jiang H, Chen C, et al. In situ growth gold nanoparticles in three-dimensional sugarcane membrane for flow catalytical and antibacterial application. J Hazard Mater. 2021;402:123445. 
7. Huang C, Fang G, Zhou Y, Du X, Yu L, Meng X, et al. Increasing the carbohydrate output of bamboo using a combinatorial pretreatment. ACS Sustain Chem Eng. 2020;8(19):7380-93.

8. Galia A, Schiavo B, Antonetti C, Galletti AMR, Interrante L, Lessi M, et al. Autohydrolysis pretreatment of Arundo donax: a comparison between microwave-assisted batch and fast heating rate flow-through reaction systems. Biotechnol Biofuels. 2015;8(1):1-18.

9. Otieno DO, Ahring BK. A thermochemical pretreatment process to produce xylooligosaccharides (XOS), arabinooligosaccharides (AOS) and mannooligosaccharides (MOS) from lignocellulosic biomasses. Bioresour Technol. 2012;112:285-92.

10. Gullón P, Salazar N, Muñoz MJG, Gueimonde M, Ruas-Madiedo P, De los Reyes-Gavilán CG, et al. Assessment on the fermentability of xylooligosaccharides from rice husks. BioResources. 2011;6(3):3096-114.

11. Huang C, Jeuck B, Du J, Yong Q, Chang HM, Jameel H, et al. Novel process for the coproduction of xylo-oligosaccharides, fermentable sugars, and lignosulfonates from hardwood. Bioresour Technol. 2016;219:600-7.

12. Sutton TA, O'Neill HVM, Bedford MR, McDermott K, Miller HM. Effect of xylanase and xylo-oligosaccharide supplementation on growth performance and faecal bacterial community composition in growing pigs. Anim Feed Sci Technol. 2021;274:114822.

13. He X, Yu B, He J, Huang Z, Mao X, Zheng P, et al. Effects of xylanase on growth performance, nutrients digestibility and intestinal health in weaned piglets. Livest Sci. 2020;233:103940.

14. Schwab CG. Feed supplements : ruminally protected amino acids amino acid nutrition of dairy cattle. Elsevier; 2011. p. 389-95.

15. Sharif M, Zafar MH, Aqib Al, Saeed M, Farag MR, Alagawany M. Single cell protein: Sources, mechanism of production, nutritional value and its uses in aquaculture nutrition. Aquaculture. 2021;531:735885.

16. Ritala A, Häkkinen ST, Toivari M, Wiebe MG. Single cell protein-state-ofthe-art, industrial landscape and patents 2001-2016. Front Microbiol. 2017:8:2009.

17. Jones SW, Karpol A, Friedman S, Maru BT, Tracy BP. Recent advances in single cell protein use as a feed ingredient in aquaculture. Curr Opin Biotechnol. 2020;61:189-97.

18. Hatoum R, Labrie S, Fliss I. Antimicrobial and probiotic properties of yeasts: from fundamental to novel applications. Front Microbiol. 2012:3:1-12.

19. Ezekiel O, Aworh O. Simultaneous saccharification and cultivation of Candida utilis on cassava peel. Innov Food Sci Emerg Technol. 2018;49:184-91.

20. Buitrago Mora HM, Piñeros MA, Espinosa Moreno D, Restrepo Restrepo S, Cardona Jaramillo JEC, Álvarez Solano A, et al. Multiscale design of a dairy beverage model composed of Candida utilis single cell protein supplemented with oleic acid. J Dairy Sci. 2019;102:9749-62.

21. dos Santos JF, Canettieri EV, Souza SMA, Rodrigues RCLB, Martínez EA. Treatment of sugarcane vinasse from cachaça production for the obtainment of Candida utilis CCT 3469 biomass. Biochem Eng J. 2019;148:131-7.

22. Kim DS, Myint AA, Lee HW, Yoon J, Lee YW. Evaluation of hot compressed water pretreatment and enzymatic saccharification of tulip tree sawdust using severity factors. Bioresour Technol. 2013;144:460-6.

23. Narron $\mathrm{RH}$, Kim H, Chang HM, Jameel H, Park S. Biomass pretreatments capable of enabling lignin valorization in a biorefinery process. Curr Opin Biotechnol. 2016:38:39-46.

24. He J, Huang C, Lai C, Huang C, Li M, Pu Y, et al. The effect of lignin degradation products on the generation of pseudo-lignin during dilute acid pretreatment. Ind Crops Prod. 2020;146:1-8.

25. Sun SN, Li HY, Cao XF, Xu F, Sun RC. Structural variation of eucalyptus lignin in a combination of hydrothermal and alkali treatments. Bioresour Technol. 2015;176:296-9.

26. Batalha LAR, Han Q, Jameel H, Chang HM, Colodette JL, BorgesGomes FJ. Production of fermentable sugars from sugarcane bagasse by enzymatic hydrolysis after autohydrolysis and mechanical refining. Bioresour Technol. 2015;180:97-105.

27. Neto FSPP, Roldán IUM, Galán JPM, Monti R, de Oliveira SC, Masarin F. Model-based optimization of xylooligosaccharides production by hydrothermal pretreatment of Eucalyptus by-product. Ind Crops Prod. 2020;154:112707.

28. Monteiro CRM, Ávila PF, Pereira MAF, Pereira GN, Bordignon SE, Zanella E, et al. Hydrothermal treatment on depolymerization of hemicellulose of mango seed shell for the production of xylooligosaccharides. Carbohydr Polym. 2021;253:117274.

29. Kidd MT, Tillman PB, Waldroup PW, Holder W. Feed-grade amino acid use in the United States: The synergetic inclusion history with linear programming. J Appl Poult Res. 2013;22:583-90.

30. Chen M, Lu J, Cheng Y, Li Q, Wang H. Novel process for the coproduction of xylo-oligosaccharide and glucose from reed scraps of reed pulp mill. Carbohydr Polym. 2019;215:82-9.

31. Sluiter A, Hames B, Ruiz R, Scarlata C, Sluiter J, Templeton D, et al. Determination of structural carbohydrates and lignin in biomass: laboratory analytical procedure (LAP); Issue Date: April 2008; Revision Date: July 2011 (Version 07-08-2011). 2011;2011.

32. AOAC. Official methods of analysis of AOAC International. Association of Official Analytical Chemists International; 2005.

33. Bradford MM. A rapid and sensitive method for the quantitation of microgram quantities of protein utilizing the principle of protein-dye binding. Anal Biochem. 1976;72(1-2):248-54.

\section{Publisher's Note}

Springer Nature remains neutral with regard to jurisdictional claims in published maps and institutional affiliations.
Ready to submit your research? Choose BMC and benefit from:

- fast, convenient online submission

- thorough peer review by experienced researchers in your field

- rapid publication on acceptance

- support for research data, including large and complex data types

- gold Open Access which fosters wider collaboration and increased citations

- maximum visibility for your research: over $100 \mathrm{M}$ website views per year

At BMC, research is always in progress.

Learn more biomedcentral.com/submissions 